\title{
Magyarország Nemzeti Atlasza
}

\author{
MTA, MÉM, Kartográfiai Vállalat, Budapest, 1989. 395 o.
}

Alapos elôkészületeket követố több éves munka tudományos szempontból is kiemelkedố eredménye az 1989 karácsonyára megjelent nemzeti atlasz. Teljes biztonsággal helyezhetố az évtized legnagyobb földrajzi teljesítményeinek sorába. A tervezési, szervezési és kiadói munkálatokat is ellátó Földrajztudományi Kutató Intézet népes munkaközösséget vezényelt. Az alkotók arra vállalkoztak, hogy a kutatások eredményei alapján bemutassák és értékeljék hazánk természeti, gazdasági és társadalmi viszonyainak változását, mai állapotát. $\mathrm{S}$ valóban, a diplomáciai kapcsolatoktól Ốriszentpéter község rendezési tervéig 19 fejezetbe csoportosított, rendkívül széles tematikai kört átfogó közel 300 térképoldalon, és 100 oldalnyi magyarázó szövegkísérettel tárul elénk a 80-as évek Magyarországa. Az atlasz nemcsak mennyiségileg, de fôként tartalmának minôségével lényegesen, mondhatni összehasonlíthatatlanul több, mint 1967-ben kiadott elôdje.

Átfogó és értékelố véleményalkotás szándékával fogtam e recenzió megírásához, de rá kellett jönnöm, hogy legfeljebb elsố benyomásaimat oszthatom meg a Tisztelt Olvasóval. Az atlasz oly nagy mennyiségú információt tartalmaz, hogy alaposabb megismeréséhez hơnapok kellenek. Ezért gyanítom, tényleges használati értéke is csak késóbb lesz megállapitható (kỏvetkezésképpen az apróbb hibákra, elírásokra, színelcsúszásokra is eközben derül majd fény).

Már elsố áttekintésre jól érzékelhetố a komplexitásra, illetve az általános és (esetenként) a jellemzố egyedi bemutatására való törekvés, és az a szándék, hogy markánsan jelenjenek meg az új kutatási eredmények, de ne csak statisztikai tényszerũségüikben, hanem a megközelítés szemléletére utalóan is. Ez különösen akkor válik nyilvánvalóvá, ha a térképeket a rendkivuil érdekes, sốt többségében külön-külön is szakmai remeklésnek minốsíthetố magyarázó szövegekkel egyủtt olvassuk.

Egy ilyen méretư atlasz olvasásához az ember többnyire nem úgy fog hozzá mint egy regényéhez. Inkább csak az érdeklỡdésének megfelelő fejezeteket böngészi. Szeretném kérni az atlasz Tisztelt Olvasóit, hogy ezúttal ne ezt tegyék, legalább egyszer lapozzák végig. Meglátják, a borkóstolási metódus itt is eredményes lesz, mind az általános minõsítés, mind a legjobb kiválasztása céljából. Én magam a társadalomföldrajzi fejezetekhez vonzódom, ezért talán (ha meg nem is bocsátható, de) érthetố, hogy azokról a térképekrổl bơvebben írok. Ám be kell vallanom, igen nagy élvezettel fedeztem fel sok érdekeset és újat más témakörư fejezetekben is. Hadd említsek meg néhányat konkrétan: a felmérés és térképezés történeti és egynémely módszertani vonását bemutató térképek; a geomorfológiai, földtani-szerkezeti, mérnök- és hidrogeológiai térképek; a történeti földtan rendkívül szemléletes térképei; a részletes éghajlati térképsorozat; a Duna vízgyũjoô területének vízföldtani térképe; a talajvizek vegyi jellegét bemutató térkép; a genetikai és a FAO talaj- 
térkép; a természeti tájak rendszertani felosztása; a tájtípusok térképe; a környezetvédelmi fejezet térképei.

A társadalomföldrajzi térképanyaggal kapcsolatban több elsố benyomásom is volt:

- ilyen gazdag, és a folyamatok bemutatására is törekvõ társadalomföldrajzi térképkollekció egy kötetben Magyarországon még nem jelent meg;

- az a mérhetetlen mennyiségú adat, amit a szerzốk összegyüjtöttek, valószínűleg még sok térkép elkészitését lehetôvé tette volna. Persze ilyenkor masszívan állnak a terjedelmi korlátok, de talán esetenként, a komplexitás növelésével a terjedelmi korlátot ki lehetett volna játszani;

- mintha a kívánatosnál kevesebb lenne a regionális térkép. Közben is, de különösen a területi tervezés térképei kapcsán jutott eszembe, hogy az öt nagyváros részletesebb bemutatást érdemelt volna;

- nagyon jó megoldásnak tartom, hogy nemcsak a népesség és települési fejezetnél, de másutt is, ahol lehetett, a statisztikai alapegységet a település képezte. Ez az atlasz használhatóságát nagy mértékben növeli.

Nem meglepố (a statisztikai adatszolgáltatás struktúrájából is következik), hogy a társadalmi és gazdasági témakörök, úgymond klasszikus csoportosításban következnek. E hagyományos fejezetelés belsổ tartalma azonban már nemcsak egy nemzeti atlaszban kötelezổen szükséges információkat adja, de sok újdonságot is felmutat, amelyek már az ismerkedố lapozgatáskor magukhoz vonzzák a figyelmet. A továbbiakban elsôsorban ezek között szeretnék tallózni.

Úgy tủnik, az újdonságok tekintetében a népesség, települések, lakás- és közmúellátottság címú fejezet emelkedik ki. Az itt közreadott térképanyag jól reprezentálja a társadalom vizsgálatának új szemléleteit. Különösen érdekesnek tartom a népesség területi eloszlását, a népsưrüség változását 1784-tổl követổ térképsorozatot; a települések vándorlási egyenlegének bemutatását; a nemzetiségi, etnikai vonatkozású térképeket; az életkörülmények térbeli megjelenítését; a falutípusoknak, valamint a települések dinamikai típusainak bemutatását; a budapesti térképsorozatot; a lakásállomány korstruktúrájának területi változásait feldolgozó térképeket.

$\mathrm{Az}$ egészségügyet ábrázoló rövid fejezet utolsó oldalánál idổztem hosszabban, ahol 12 kis térképen és 7 grafikonon tömérdek információ olvasható a lakosság egészségi állapotáról. Az oktatás, közmũvelổdés, sport témakörứ fejezetben a lakosság képzettségi színvonalát, valamint az ország szellemi központjait bemutató térképek hatottak az újszerũség varázsával.

Terjedelmes fejezet foglalkozik az ipar és építôipar témaköreivel. A ,,kötelezô"' információk (ágazatok, termékek részletezése) mellett itt is találni számos új elemet. Ilyen például a foglalkoztatottak megoszlása üzemnagyság szerint; vagy a foglalkoztatottak életkorának megyénkénti alakulása; a magánipar ágazati és területi elhelyezkedése; egyes vegyipari vállalatok termelési szerkezetének bemutatása.

A mezốgazdaság és élelmiszeripar szintén sok, el nem hagyható ágazati- és termékbemutatást követel (talán kissé túlzott is az atlaszban ennek mérete). Ám szerencsére itt is sikerült elhelyezni nem egy novumot. Különösen tetszik néhány régió földhasznosításának bemutatása; a termốföld értékelésének térképrevitele; az alaptevékenység arányának ismertetése. Kár, hogy a mezôgazdaság térbeli termelési kapcsolatairól nem készült térkép. Ellenben nagyszerũ ötlet volt a termelési színvonal, a vállalati hatékonyság, a jövedelmezôség és az újratermelés saját forrásai területi szerkezetének közzététele.

A közlekedés, posta és távközlés térképei, 
ezen ágazatok jellegébổl következôen fő́ként hálózatokat, irányokat mutatnak. Közöttük a megyeszékhelyek elérhetôségét ábrázoló térkép viszonylagos komplexitásával tûnik ki.

Igazán kár, hogy a belkereskedelem, vendéglátás és szolgáltatás mindössze hét térképoldalt kapott. A kitünően felépített térképekrổl árad az információbőség. Az embernek az az érzése, hogy a szerzốk sajnáltak bármit is kihagyni a birtokukban lévô információhalmazból. Ha lehetôségük van, bizonyára ide jól illố regionális térképeket is elhelyeztek volna.

Érdekes kísérlet az idegenforgalom vonzó tényezôinek térképi összefoglalása. Különösen tanulságos ezt összevetni az idegenforgalmi tájegységek látogatottságát feldolgozó térképpel. Ez utóbbi, 1984-es adatok alapján, a határállomások forgalmát is közli. A történések azonban ezt a térképet azóta alaposan átírták. A magyar világútlevél, a szovjet utazási könnyítések és más változások nagyságrendekkel növelték az utazási mennyiségeket. Az atlasz újabb kiadásakor remélhetőleg lesz lehetôség korrekcióra, vagy a változás valamiféle jelzésére.
Úgy tũnik, a külkereskedelem számára adott méltatlanul szerény terjedelembôl származó gondokat a szerzốk úgy próbálták áthidalni, hogy ha már részletesek nem, legalább szemléletesek legyenek. Ez sikerült is, de a hiányérzetet alig oszlatja.

$\mathrm{Az}$ atlasz térképegységét a területi tervezés címũ fejezet zárja. A témakörnek a nemzeti atlaszban való elhelyezését nemcsak egyszerüen jó ötletnek, de kifejezetten szükségesnek tartom. Az itt közölt térképek kettôs funkciót töltenek be: egyrészt mint térképek önmagukban is elemezhetốk, másrészt az ide kapcsolódó magyarázó szöveg kitûnổ illusztrációi is. A térképek és a magyarázó sorok együtt frappáns segítséget adnak a területi tervezés lényegének megértéséhez.

Szívesen ajánlom ezt a kiváló munkát mindazok figyelmébe, akiket mélyebben érdekel hazánk földje, népe, gazdasága. De igazán akkor leszek boldog, ha ezt az atlaszt, mint rendszeresen használt munkaeszközt, a jelenünket és jövổnket formáló, legkülönböző̉bb szintú döntéshozók asztalán tudhatom.

Mészáros Rezsố 